\title{
Seasonal dynamics and net production of dissolved organic carbon in an oligotrophic coastal environment
}

\author{
Gemma Vila-Reixach ${ }^{1, *}$, Josep M. Gasol ${ }^{2}$, Clara Cardelús ${ }^{2}$, Montserrat Vidal $^{1}$ \\ ${ }^{1}$ Departament d'Ecologia, Facultat de Biologia, Universitat de Barcelona, Diagonal 645, 08028 Barcelona, Catalunya, Spain \\ ${ }^{2}$ Departament de Biologia Marina i Oceanografia, Institut de Ciències del Mar-CSIC, 08003 Barcelona, Catalunya, Spain
}

\begin{abstract}
To understand dissolved organic carbon (DOC) seasonal dynamics in a coastal oligotrophic site in the north-western Mediterranean Sea, we monitored DOC concentrations monthly over $3 \mathrm{yr}$, together with the meteorological data and the food-web-related biological processes involved in DOC dynamics. Additional DOC samples were taken in several inshore-offshore tran-

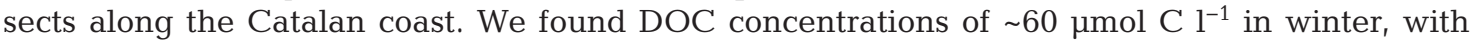
increasing values through the summer and autumn and reaching 100 to $120 \mathrm{mmol} \mathrm{C} \mathrm{l}^{-1}$ in November. There was high inter-annual variability in this summer DOC accumulation, with values of 36, 69 and $13 \mu \mathrm{mol} \mathrm{C} \mathrm{l}^{-1}$ for 2006, 2007 and 2008, respectively. The analysis of the microbial food-web processes involved in the DOC balance did not reveal the causes of this accumulation, since the only occasion on which we observed net DOC production $\left(0.3 \pm 1 \mu \mathrm{mol} \mathrm{C} \mathrm{l}^{-1} \mathrm{~d}^{-1}\right.$ on average) was in 2007, and the negative DOC balance of 2006 and 2008 did not prevent DOC accumulating. The DOC accumulation episodes coincided with low rates of water renewal (average $0.037 \pm 0.021 \mathrm{~d}^{-1}$ from May to October) compared with those of winter to early spring (average $0.11 \pm 0.048 \mathrm{~d}^{-1}$ from November to April). Indeed, the amount of DOC accumulated each year was inversely correlated with the average summer rainfall. We hypothesize that decreased DOC turn-over due to photochemical or biological processes - mostly active during the summer-and low water renewal rate combine to determine seasonal DOC accumulation and influence its inter-annual variability.
\end{abstract}

KEY WORDS: Coastal DOC $\cdot$ Seasonality $\cdot$ Primary production $\cdot$ Bacterial metabolism $\cdot$ Physical transport

\section{INTRODUCTION}

Dissolved organic carbon (DOC) is one of the largest exchangeable carbon reservoirs on Earth. The global marine DOC pool is estimated to contain 685 GT C (Hansell \& Carlson 1998a), comparable to the mass of inorganic $\mathrm{C}$ in the atmosphere (Fasham et al. 2001). Small perturbations in the production or in the transport of the oceanic DOC pool could have drastic impacts in the balance between oceanic and atmospheric $\mathrm{CO}_{2}$ (Carlson 2002).
DOC is produced through different processes, such as phytoplankton excretion, egestion and release by grazers, viral cell lysis, and the enzymatic hydrolysis of detritus and aggregates (Biddanda \& Benner 1997, Biersmith \& Benner 1998, Fajon et al. 1999, Nagata 2000, Sintes et al. 2010), and heterotrophic bacteria are the main consumers of DOC. Decoupling between production and consumption processes can cause the accumulation of DOC. Indeed, seasonal DOC accumulation has been found in the surface waters of different regions such as the Baltic Sea 
(Zweifel et al. 1995), the north-western Mediterranean (Copin-Montégut \& Avril 1993) and the Sargasso Sea (Carlson et al. 1994). Accumulated DOC can be subsequently transported by convective or mixing processes and surface currents, therefore contributing to the carbon balance of adjacent regions. The potential for DOC transfer is thus dependent on its residence time in the water and on the biological availability of the DOC pool to bacteria.

In terms of its availability, DOC consists of a broad spectrum of molecules: (1) labile DOC that is readily usable by bacteria turning over in time scales of hours to days, (2) semi-labile DOC that resists rapid microbial degradation turning over on seasonal to annual time scales and (3) refractory DOC with turnover times of millennia (Carlson 2002). Some processes, such as protozoan grazing and viral lysis, are known to be particularly important in producing refractory DOC, as reported by Strom et al. (1997) and Suttle (2007). Both, the refractory nature of DOC and the limited availability of inorganic nutrients can inhibit DOC utilization by bacteria and can thus contribute to DOC accumulation (Legendre \& Le Fèvre 1995, Thingstad et al. 1997, Carlson et al. 2002). As a consequence, the composition and refractory nature of DOC can vary depending on the trophic structure and the environmental conditions of the ecosystem (Carlson et al. 2002). Despite the widespread occurrence of DOC accumulation in a wide variety of oceanic and coastal ecosystems (Copin-Montégut \& Avril 1993, Carlson et al. 1994, Børsheim \& Myklestad 1997), the reasons for the accumulation of semilabile and refractory DOC pools have remained elusive.

Coastal ecosystems play a significant role in ocean carbon cycling because they concentrate $20 \%$ of oceanic primary production (Schlesinger 1997) and they represent the linkage between terrestrial sources of organic matter and the open ocean. In coastal waters allochthonous inputs from rivers and runoff provide DOC compounds of different lability (Cauwet 2002). Besides, physical features like morphology, tidal or microtidal processes, surface waves and currents can have drastic effects on the distribution and the residence time of phytoplankton assemblages, nutrients and water masses on the shelf (Font et al. 1995, Sabatés et al. 2001, Bolaños et al. 2009). These processes confer high variability to coastal ecosystems and, as a result, generate high spatial and temporal DOC variability. In particular, water renewal is a key factor in the modulation of nearshore algal blooms (Basterretxea et al. 2007) and, as we hypothesize, can play a role in DOC dynamics.
In the present study we (1) determine the magnitude and extent of DOC accumulation in a northwestern Mediterranean coastal area; (2) we estimate the net production of DOC from the mass balance of the different food-web-related processes involved; and (3) we assess the role of physical factors, in particular water renewal rate, in the seasonal DOC accumulation and its interannual variability. The analysis is based on $3 \mathrm{yr}$ of monthly field measurements of DOC concentrations, primary and bacterial production, community respiration and numerical estimations of the wind-induced water renewal from meteorological and hydrological data. These data are combined with 4 yr of extensive seasonal DOC sampling along the surrounding coast to explore whether our findings can be extrapolated to a wider area.

\section{MATERIALS AND METHODS}

\section{Study site and sampling}

The present study was conducted on the Catalan coast, north-western (NW) Mediterranean Sea (Fig. 1), where a monthly sampling was performed at the Blanes Bay Microbial Observatory (BBMO; Fig. 1). Blanes Bay is an open and exposed coastal area, located between the submarine Blanes Canyon to the north and the mouth of the La Tordera River to the south, characterised by shallow and oligotrophic waters which are seasonally mixed (Duarte et al. 1999). The BBMO sampling point is located $1 \mathrm{~km}$ offshore. Monthly samples were taken from January 2006 to December 2008, and analysed for dissolved inorganic nutrients, chlorophyll and DOC concentrations, primary and bacterial production, and community respiration. Four additional stations, in an inshore-offshore transect which included the BBMO station, were occupied once per season between April 2006 and May 2007 and sampled for DOC determinations. The 3 additional stations were located at $0.5 \mathrm{~km}$ (Stn 1), $3.5 \mathrm{~km}$ (Stn 3) and $7 \mathrm{~km}$ (Stn 4 at >100 m depth) from the coast (Fig. 1). Additional DOC samples were taken once per season between 2005 and 2008 in 4 more stations distributed along $300 \mathrm{~km}$ of the Catalan coast (see Fig. 1). These stations were located $7 \mathrm{~km}$ from the coast over depths of $\sim 100$ to $200 \mathrm{~m}$. In both seasonal studies, water samples were taken with Niskin bottles attached to a Sea-Bird SBE25 CTD and immediately processed for DOC analysis. In the monthly BBMO study, surface waters were filtered through a $200 \mu \mathrm{m}$ net and transported to the laboratory under dim light in 251 polycarbonate carboys. 


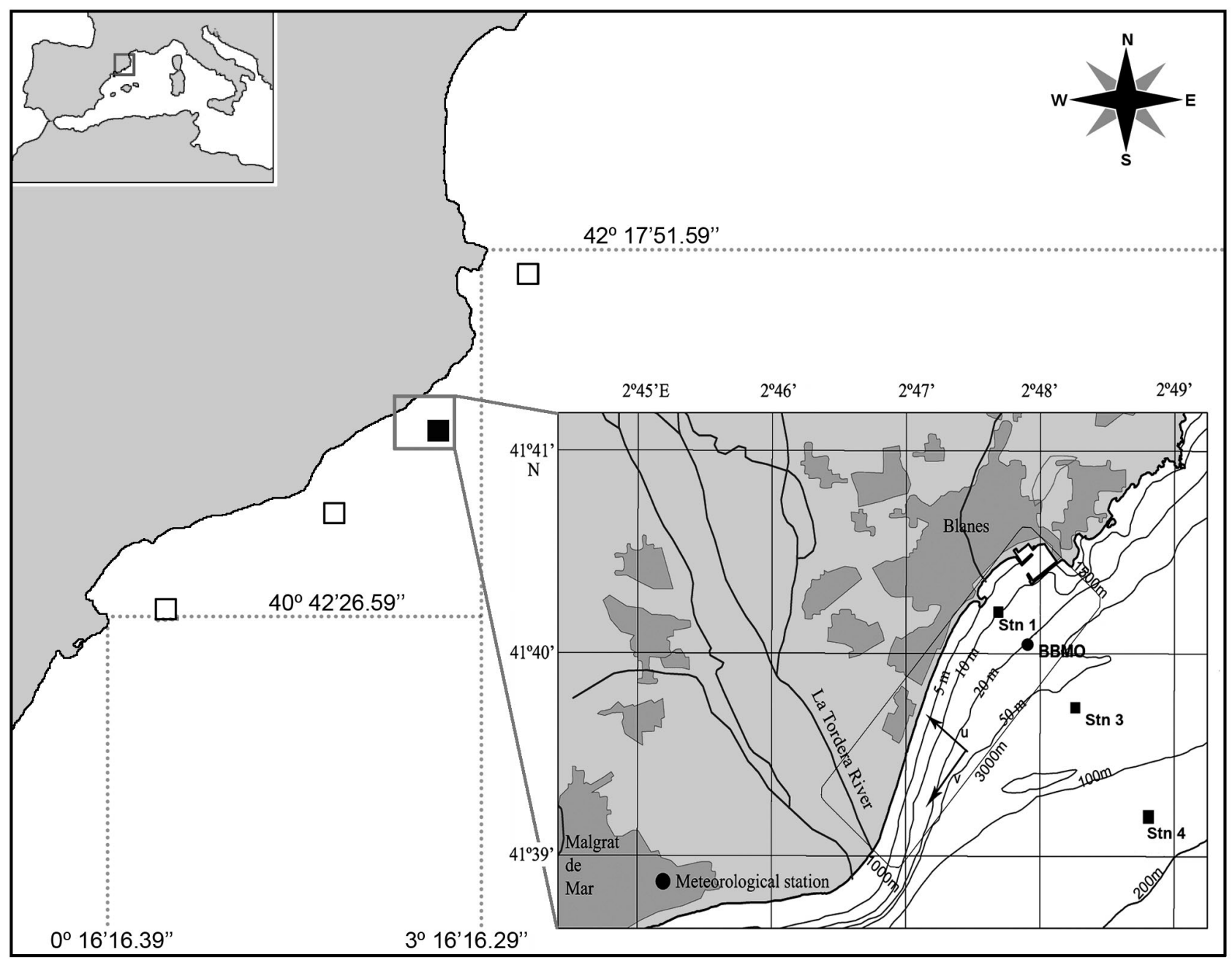

Fig. 1. Background: sampling stations along the Catalan coast. Lower right inset: stations of the inshore-offshore transect ( $\square)$ with the monthly sampled station at Blanes Bay Microbial Observatory (BBMO, $41^{\circ} 40^{\prime} \mathrm{N}, 2^{\circ} 48^{\prime} \mathrm{E}$, $\bullet$ ), La Tordera River and the Malgrat de Mar meteorological station. The area from the mouth of the Tordera River to Blanes harbour, delimited by the rectangle in the figure, was used to calculate the water renewal

Temperature was measured in situ with a mercury thermometer or a SAIV/AS SD204 CTD probe.

\section{Chemical analysis}

For determination of $\mathrm{chl}$ a concentration, $150 \mathrm{ml}$ of seawater were filtered through GF/F filters (Whatman). Subsequently, filters were extracted in acetone $(90 \% \mathrm{v} / \mathrm{v})$ in the dark at $4^{\circ} \mathrm{C}$ for $24 \mathrm{~h}$. Fluorescence was measured with a Turner Designs fluorometer. Samples for dissolved inorganic nutrients and DOC analysis were filtered through precombusted $\left(450^{\circ} \mathrm{C}\right.$, $4 \mathrm{~h}) 47 \mathrm{~mm}$ diameter Whatman GF/F filters in an acid-cleaned glass filtration system, under low $\mathrm{N}_{2}$ flow pressure. Samples for dissolved inorganic nitrogen (DIN $=\mathrm{NO}_{3}{ }^{-}, \mathrm{NO}_{2}{ }^{-}$and $\mathrm{NH}_{4}{ }^{+}$) and soluble reac- tive phosphorus (SRP) analyses were collected in $30 \mathrm{ml}$ polypropylene and $60 \mathrm{ml}$ polycarbonate bottles, respectively, and kept frozen $\left(-20^{\circ} \mathrm{C}\right)$ until analyses, which were completed before 6 mo. DIN concentrations were measured spectrophotometrically with an Alliance Evolution II autoanalyzer following standard procedures (Grasshoff et al. 1999). SRP concentrations were determined manually using the procedure of Grasshoff et al. (1999), with a Shimadzu UVprobe spectrophotometer using a $10 \mathrm{~cm}$ cuvette to increase the detection limit $\left(\mathrm{SRP}=0.01 \mu \mathrm{mol} \mathrm{P}^{-1}\right)$. Samples for the analysis of DOC were collected in $60 \mathrm{ml}$ precombusted $\left(450^{\circ} \mathrm{C}, 4 \mathrm{~h}\right)$ amber glass bottles. After the addition of $\mathrm{HgCl}_{2}$, the bottles were sealed with a polyethylene cap and stored in the dark at $4^{\circ} \mathrm{C}$ until analysis. After decarbonation of the sample by addition of $5 \% \mathrm{HCl}(2 \mathrm{M})$ and by vigorous stirring 
with high-purity synthetic air for $10 \mathrm{~min}, 150 \mu \mathrm{l}$ were injected into the vertical furnace $\left(720^{\circ} \mathrm{C}\right)$ filled with platinum catalyst, which was changed approximately every month of analysis. The $\mathrm{CO}_{2}$ from the oxidation of DOC was measured with the carbon-specific infrared gas analyser of a Shimadzu TOC-5000 organic carbon system. The system was standardised weekly with potassium hydrogen phthalate. The concentration of DOC was determined by subtracting the average peak area of 3 aliquots from the instrument blank area and dividing by the slope of the standard curve. The precision of the measurements was $\pm 1.5 \mu \mathrm{mol} \mathrm{C} \mathrm{l}^{-1}$ for carbon. Accuracy was tested daily with the DOC reference materials provided by Prof. D. Hansell (University of Miami). We obtained an average concentration of $44.4 \pm 1.0 \mu \mathrm{mol} \mathrm{C} l^{-1}(\mathrm{n}=46)$ for the deep ocean references (Florida Strait deep water, $700 \mathrm{~m}$ ). The nominal value provided by the

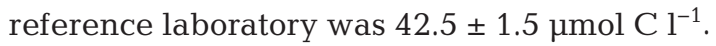

\section{Bacterial heterotrophic production}

Bacterial heterotrophic production (BP) was measured using the $\left[{ }^{3} \mathrm{H}\right]$-leucine (Leu)-incorporation method (Kirchman et al. 1985). For each sample, triplicate or quadruplicate aliquots $(1.2 \mathrm{ml})$ and 1 or 2 trichloroacetic acid (TCA)-killed controls were incubated with $40 \mathrm{nmol} \mathrm{l^{-1 }}$ Leu for $\sim 2 \mathrm{~h}$ at in situ temperature in the dark. The incorporation was stopped with the addition of $120 \mu \mathrm{l}$ of cold TCA $50 \%$ to the vials, and samples were kept frozen at $-20^{\circ} \mathrm{C}$ until processing, which was carried out by the centrifugation method of Smith \& Azam (1992). The samples were then counted on a Beckman scintillation counter $24 \mathrm{~h}$ after the addition of $1 \mathrm{ml}$ of scintillation cocktail (Optiphase Hisafe2, Perkin-Elmer). We converted leucine incorporation into biomass production with a theoretical conversion factor of $1.5 \mathrm{~kg} \mathrm{C} \mathrm{mol}^{-1} \mathrm{Leu}_{\text {, a }}$ factor that assumes no dilution with external leucine.

\section{Community respiration}

Community respiration (CR) was measured by following changes in dissolved oxygen during dark incubations of $200 \mu \mathrm{m}$ filtered water. Borosilicate glass bottles were carefully filled, and 4 to 8 replicates were immediately fixed with Winkler reagents to determine the initial oxygen concentration. Eight to 10 replicate bottles were incubated in the dark at in situ temperature and fixed with Winkler reagents after $24 \mathrm{~h}$. Dissolved oxygen measurements were made with an automatic titrator (DL50 Graphix, Mettler Toledo) based on potentiometric endpoint detection (Oudot et al. 1988). The rate of respiration was determined from the change between the initial and final oxygen concentrations. This estimation assumes that the disappearance of oxygen is linear and the slope of the regression is equal to the respiration rate. We assumed a respiratory quotient $(\mathrm{RQ}=$ $\Delta \mathrm{CO}_{2} /-\Delta \mathrm{O}_{2}$ ) of 0.88 (Williams \& del Giorgio 2004).

\section{Primary production}

For the measurement of particulate primary production (pPP), thirteen $70 \mathrm{ml}$ plastic bottles (Corning) and 1 dark control were filled with seawater and inoculated with $10 \mu \mathrm{Ci} \mathrm{NaH}{ }^{14} \mathrm{CO}_{3}$. The incubation was carried out in a water bath at in situ temperature for $2 \mathrm{~h}$ in a gradient of light irradiance (ca. 10 to $1000 \mu \mathrm{mol}$ photons $\mathrm{m}^{-2} \mathrm{~h}^{-1}$ ). Light was measured with a small size spherical light meter (Illuminova AB). After incubation, the samples were filtered at low vacuum pressure through cellulose ester filters (Millipore $0.22 \mu \mathrm{m})$, and the filters were subsequently exposed overnight to fumes of concentrated $\mathrm{HCl}$. Scintillation cocktail (4 ml Optiphase Hisafe 2) was added to each filter, and the radioactivity was measured in a Beckman LS6000 scintillation counter. Total in situ pPP was determined from the $P-E$ curve, and the in situ irradiance was obtained with a Li-Cor sensor (Li193S). Dissolved primary production (dPP), i.e. the amount of fixed $\mathrm{C}$ immediately released by phytoplankton, was obtained with the equation of Morán et al. (2002), as log dPP $=0.62 \times \log \mathrm{pPP}-1.03\left(\mathrm{r}^{2}=\right.$ $0.68, \mathrm{p}<0.000001, \mathrm{n}=40$ ). Total primary production (tPP) was estimated from the particulate and dissolved fractions $(\mathrm{tPP}=\mathrm{pPP}+\mathrm{dPP})$.

\section{Net DOC production}

The net DOC production by the microbial community was computed from the different processes of addition and removal of DOC as follows: Net $\triangle \mathrm{DOC}=$ $\mathrm{dPP}+\mathrm{E}+\mathrm{V}-\mathrm{BP}-\mathrm{BR}$ (Eq. 1), where dPP is dissolved primary production, $\mathrm{E}$ is DOC contributed by microzooplankton and heterotrophic nanoflagellate excretion, V is DOC supplied by viral cell lysis, BP is bacterial production and $\mathrm{BR}$ is bacterial respiration. DOC heterotrophic excretion, E, was estimated from the rates of microzooplankton and protist ingestion measured at the same station (Boras et al. 2009, GutiérrezRodríguez et al. 2011), assuming $20 \%$ of $\mathrm{C}$ removal was 
excreted as DOC (Nagata 2000). Microzooplankton removed $\sim 56 \%$ of daily primary production (GutiérrezRodríguez et al. 2011), while protists removed $~ 33 \%$ of daily bacterial production (Boras et al. 2009). The DOC supplied by viral cell lysis (V) was estimated from Boras et al. (2009) who found a virus removal rate of between 12.3 and $40.9 \%$ of daily bacterial production in the BBMO. Hence, total DOC production results from the addition of $\mathrm{dPP}, \mathrm{E}$ and $\mathrm{V}$. Later, we consider tPP to also include subsequent DOC release from particulate production due to enzymatic breakdown as well as other unaccounted sources, like those from gelatinous plankton and copepods, because the turnover time of this material is rapid and not sampled at the appropriate scale in our study. With respect to the biological processes that remove DOC, BR was estimated from the measured $\mathrm{CR}$, assuming it represents $71 \%$ of CR (Alonso-Sáez et al. 2008).

\section{Meteorological and hydrological data}

Meteorological data were obtained from the nearby station of Malgrat de Mar (Catalan Meteorological Service, www.meteo.cat). The station recorded vectoraveraged hourly wind direction. As an estimate of terrestrial runoff, we used discharge data from the $\mathrm{La}$ Tordera River, which discharges south of the sampling site. We used the discharge values $\left(\mathrm{m}^{3} \mathrm{~s}^{-1}\right)$ measured at the Can Serra station. Water renewal rate in the coastal area was calculated considering the area shown in Fig. 1. Wind coordinates were conveniently rotated as displayed in the figure. Two elements have been considered as major forces regulating water renewal: (1) wind-induced currents and (2) riverine discharges of the Tordera River. To calculate the wind-induced transport we have used the classic Ekman layer solution for finite depth as in Price et al. (1986). The fluid is forced by wind stress at the top of the column $(z=0)$. The lower boundary condition is free-slip to minimize the effect of finite depth.

\section{Statistical treatment}

Correlations between parameters were performed using Pearson's correlation coefficient (r). When the number of samples was low (i.e. $\mathrm{n}<20$ ), correlations between parameters were estimated using nonparametric Spearman's rho correlation coefficient ( $\rho$ ). A Shapiro-Wilk $W$-test was used to check that data were distributed normally. A Kruskal-Wallis ANOVA test was used to identify significant differences be- tween seasons. These statistical analyses were performed using STATISTICA 7 software.

\section{RESULTS}

\section{Environmental conditions}

Coastal winds were highly variable in strength and direction though significant seasonal patterns were observed. Wind seasonality was determined by strong north-western (NW) winds during winter and weak south-eastern (SE) winds in summer (Fig. 2). Since major changes are attributed to variations in alongshore winds, we estimated changes on coastal water renewal based only on this component of wind stress. Mean alongshore currents from 3 to $8 \mathrm{~cm} \mathrm{~s}^{-1}$ were estimated with increases of up to $35 \mathrm{~cm} \mathrm{~s}^{-1}$ during the most energetic winter events. The corresponding water renewal rates are shown in Fig. 3. Water renewal was highly seasonal, with very low values in summer (average $0.037 \pm 0.021 \mathrm{~d}^{-1}$ from May to October). Flow through La Tordera River ranged between 0.03 and $60 \mathrm{~m}^{3} \mathrm{~s}^{-1}$, with highest values in winter and spring (Fig. 4a). Wind-induced coastal flow plays an important role in determining the characteristics of the buoyant plume of the La Tordera River. During the winter, when the prevailing coastal currents are southwards, the influence of the river in the study area should be low. More influence could be expected during summer, but river discharge in this season is almost negligible (Fig. 4a). We have estimated that the effect of the river is only relevant at very short timescales under northward alongshore flow conditions. This does not exclude other freshwater contributions such as run-off from diffuse sources, which can be related to precipitation events. Daily precipitation varied between $0 \mathrm{~mm}$ and maximums of 40 to $60 \mathrm{~mm}$, showing low values in the summer and autumn and high inter-annual variability (Fig. 4b). This inter-annual variability affected, in particular, the summer and autumn, with average daily precipitation from July to October of 0.044, 0.003 and 0.074 $\mathrm{mm}$, in 2006, 2007 and 2008, respectively.

There was strong seasonality in water characteristics, with temperature ranging from 12 to $26^{\circ} \mathrm{C}$ and salinity from 36.3 and 38.3 psu (Fig. 5a). High salinity was frequently found during late autumn and winter. $\mathrm{NO}_{3}^{-}+\mathrm{NO}_{2}^{-}$and SRP showed the same seasonal pattern as salinity, increasing to values of $\sim 4$ and $0.5 \mu \mathrm{mol} \mathrm{l}{ }^{-1}$, respectively, in winter (Fig. 5b). $\mathrm{NH}_{4}{ }^{+}$ concentrations were more variable and exceeded $\mathrm{NO}_{3}{ }^{-}+\mathrm{NO}_{2}{ }^{-}$concentrations in summer and autumn. 

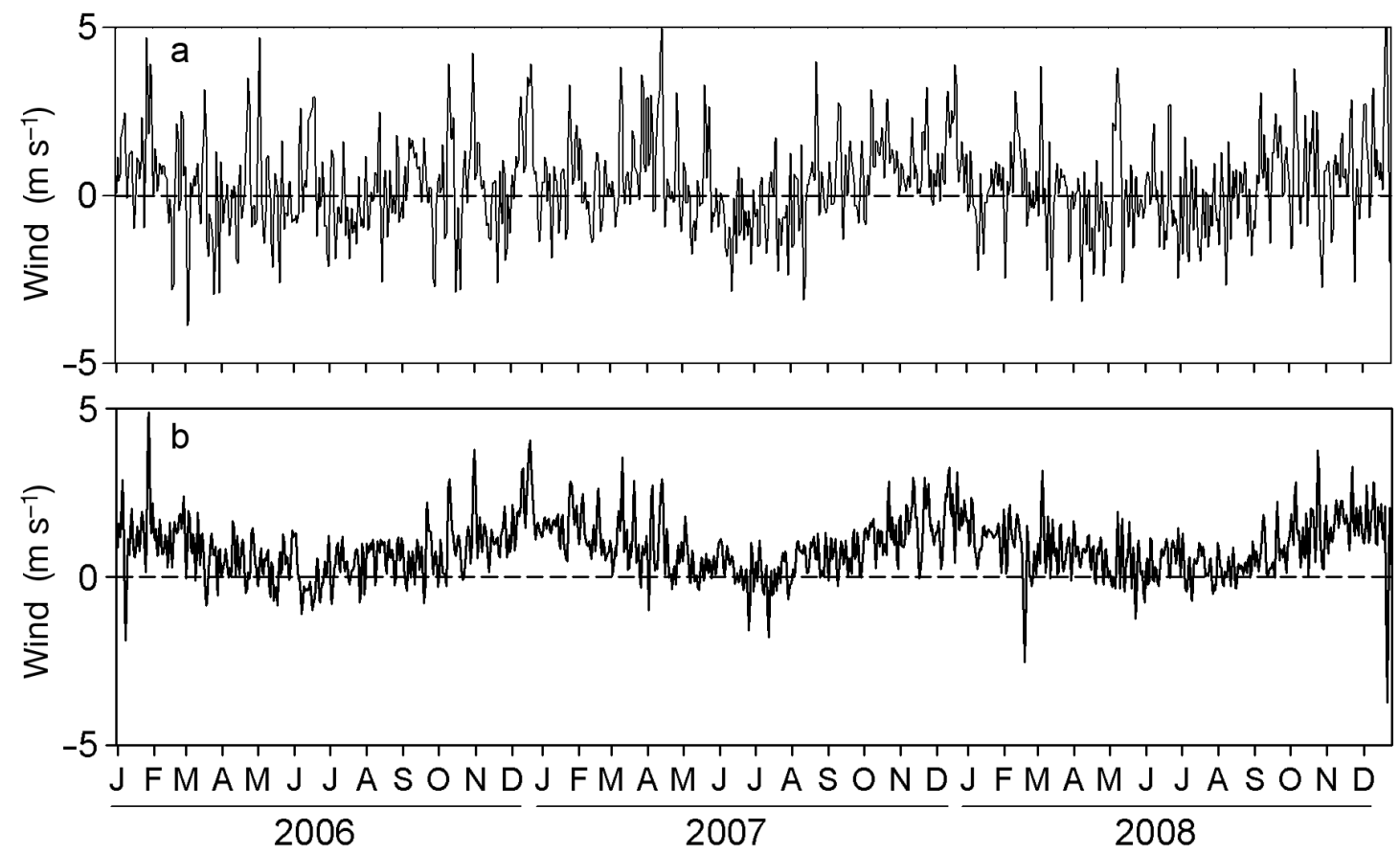

Fig. 2. Time course of (a) inshore-offshore and (b) alongshore components of daily averaged winds over the 3 yr. Seasonal differences mainly occur in the alongshore flow that is to the south during winter and notably weakens in summer

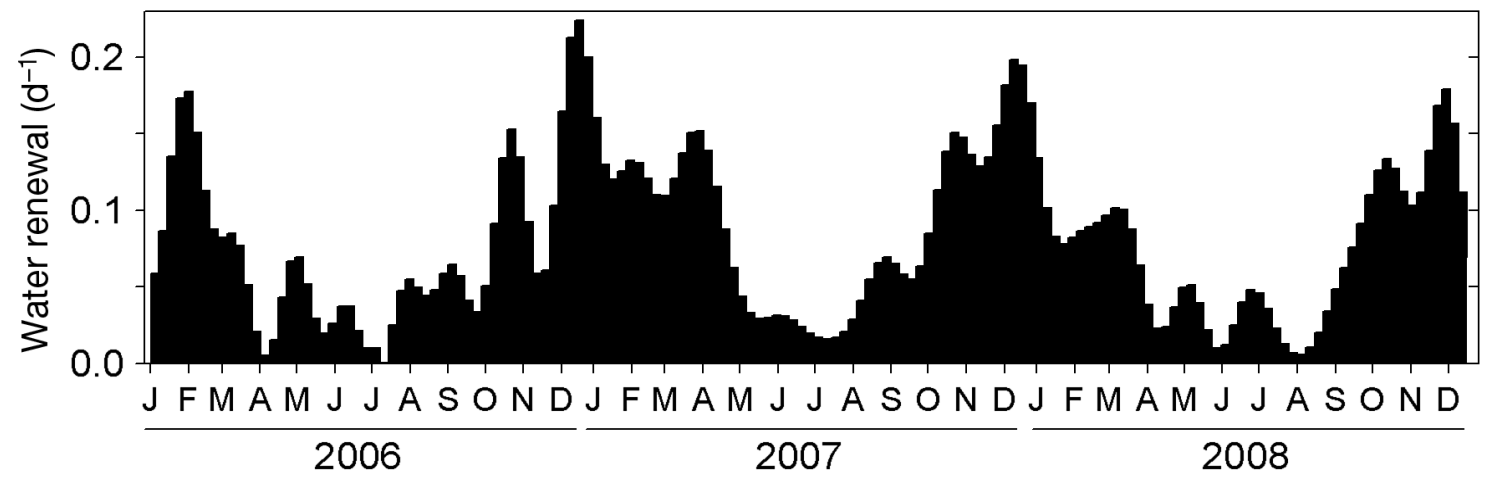

Fig. 3. Water renewal rate considering only wind forcing (weekly values) from the alongshore component wind over the 3 yr

Low concentrations of SRP and $\mathrm{NO}_{3}{ }^{-}+\mathrm{NO}_{2}{ }^{-},<0.05$ and $1 \mathrm{umol} \mathrm{l}^{-1}$, respectively, were found during summer, concurrent with the lowest chl $a$, of about $0.1 \mu \mathrm{g}$ $\mathrm{l}^{-1}$. Chl a increased to $>1 \mu \mathrm{g} \mathrm{l}^{-1}$, in early winter, soon after the increase of $\mathrm{NO}_{3}^{-}+\mathrm{NO}_{2}^{-}$and SRP concentrations. DIN:SRP ratios ranged between 10:1 and $>300: 1$, showing the highest values in 2007 (average for May to November of 45:1, 82:1 and 58:1, for 2006, 2007 and 2008, respectively).

\section{Dissolved organic carbon concentrations}

DOC showed high variability, with low values, of $\sim 60 \mu \mathrm{mol} \mathrm{C} \mathrm{l}^{-1}$, in winter, higher concentrations around early spring, and a trend of increasing DOC during the summer and early autumn, reaching concentrations of $\sim 100$ to $120 \mu \mathrm{mol} \mathrm{Cl} l^{-1}$ in November (Fig. 5c). Nevertheless, there was high inter-annual variability in the extent of both, the spring and the summer/autumn increases. In this respect, the surplus of summer/autumn accumulated DOC was of 36,

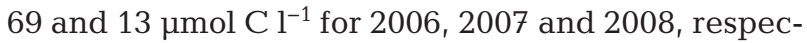
tively. Summer increases of DOC were also observed at the other stations studied: along the inshore-offshore transect and the Catalan coast, with significantly higher concentrations in summer than in the rest of the year ( $p<0.001, n=67$; Fig. 6$)$. In these cases the highest peak of DOC in autumn was not observed, probably because the sampling was at the 


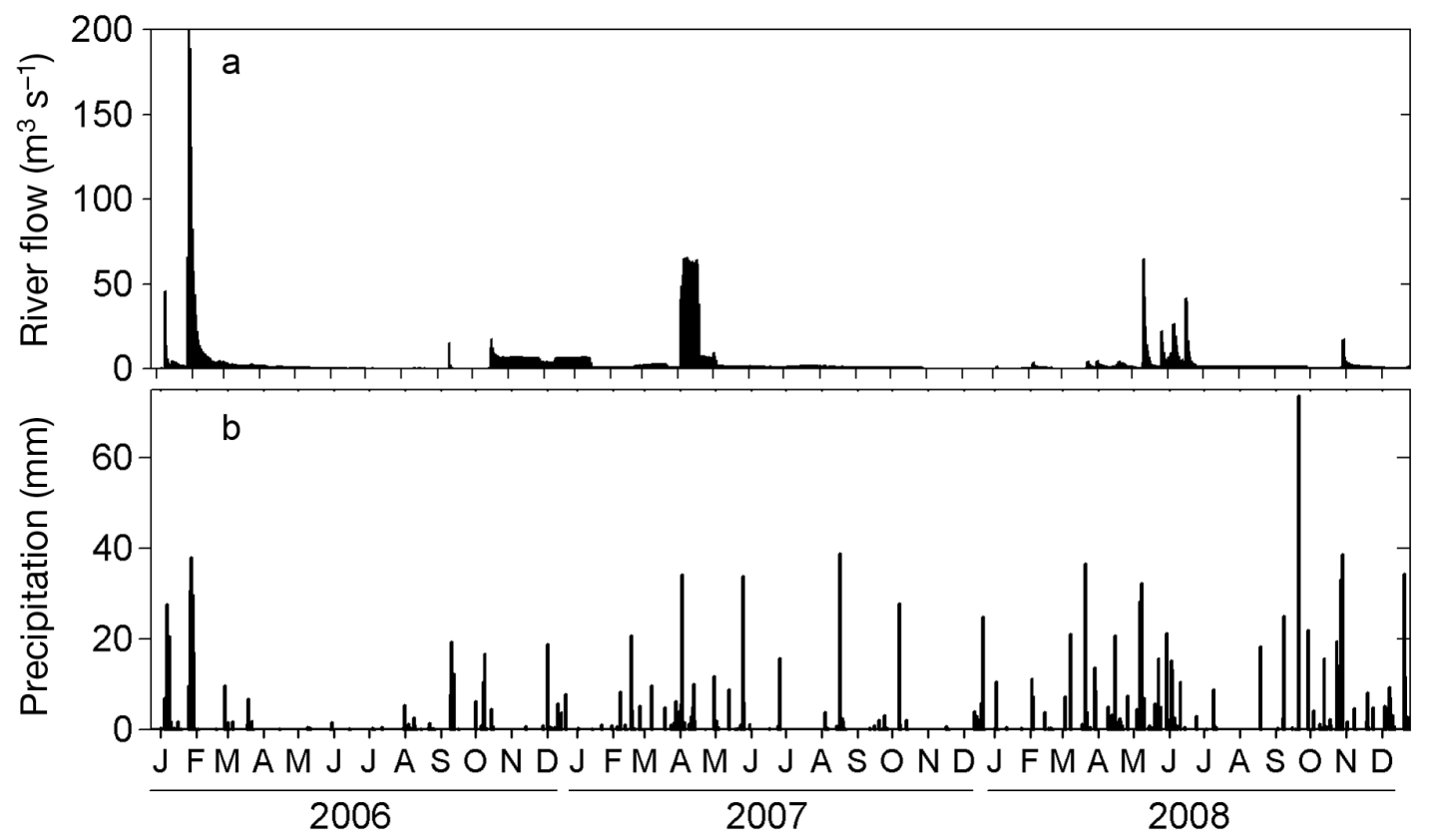

Fig. 4. (a) La Tordera flow daily values and (b) daily accumulated rainfall at Malgrat de Mar meteorological station over the 3 yr

end of November. All this suggests that summer DOC accumulation was a widespread phenomenon and not an idiosyncratic characteristic of Blanes Bay.

\section{Seasonal cycles of primary production, bacterial production and community respiration}

Particulate primary production (pPP) ranged from

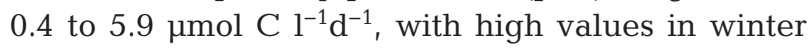
and spring, low values in summer and occasional peaks in autumn (Fig. 7a). BP showed median values

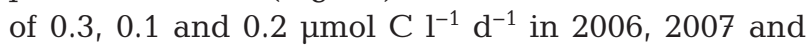
2008, respectively, and some occasional increases in spring and summer. CR ranged from 0.2 to $4.7 \mu \mathrm{mol}$

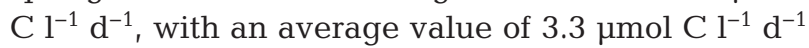
(Fig. 7a).

\section{Net DOC production}

Fig. $7 \mathrm{~b}$ shows the time course of the main processes involved in the DOC balance. Phytoplankton dissolved production (dPP) was relatively invariant,

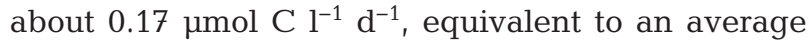
percent extracellular release $(\mathrm{PER}=\mathrm{dPP} / \mathrm{dPP}+\mathrm{pPP})$ of $11 \%$. An equivalent amount of DOC, of about

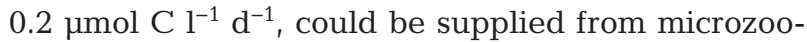
plankton and heterotrophic nanoflagellate excretion (E). Cell viral lysis (V) contributed to a lower amount

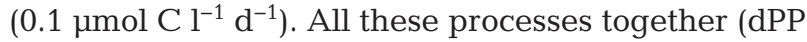

$+\mathrm{E}+\mathrm{V}$ ) would yield DOC at a rate of about $0.5 \mu \mathrm{mol} \mathrm{C}$

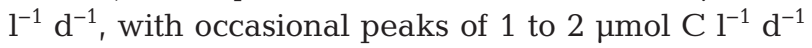
(Fig. 7b). The inclusion of tPP instead of dPP in Eq. (1) increased the production of DOC to about $2.2 \mu \mathrm{mol} \mathrm{C}$ $\mathrm{l}^{-1} \mathrm{~d}^{-1}$ on average, with occasional peaks of $7 \mu \mathrm{mol} \mathrm{C}$

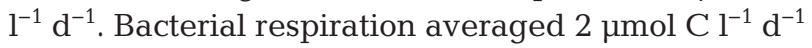
and contributed to about $80-90 \%$ of the bacterial carbon demand (BCD). Yet BCD exceeded the potential DOC sources on 17 out of 28 occasions (Fig. 7b), yielding negative values of net DOC production (Fig. 8). Nevertheless, there was considerable variability in this respect, with more balanced net DOC in 2007, compared to 2006 and 2008. Net DOC production was of $0.3 \pm 1 \mu \mathrm{mol} \mathrm{C} \mathrm{l}^{-1} \mathrm{~d}^{-1}$ on average during the first half of 2007. This surplus DOC can justify the seasonal

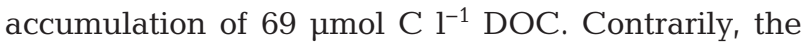
dominant negative DOC production of 2006 and 2008

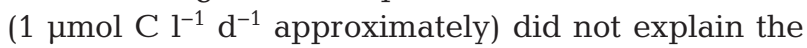
accumulation of 35 and $13 \mu \mathrm{mol} \mathrm{Cl}{ }^{-1}$, respectively. Although we only have 3 study years, the amount of DOC accumulated each year was inversely correlated with the July-to-October averaged daily precipitation (Spearman correlation test, $\rho=-1, \mathrm{p}<0.01, \mathrm{n}=3$ ).

\section{DISCUSSION}

DOC accumulation was observed through the Catalan coast at different scales: in an extensive sampling from north to south along the coast, in an inshore-offshore transect (Fig. 6), and at the BBMO 

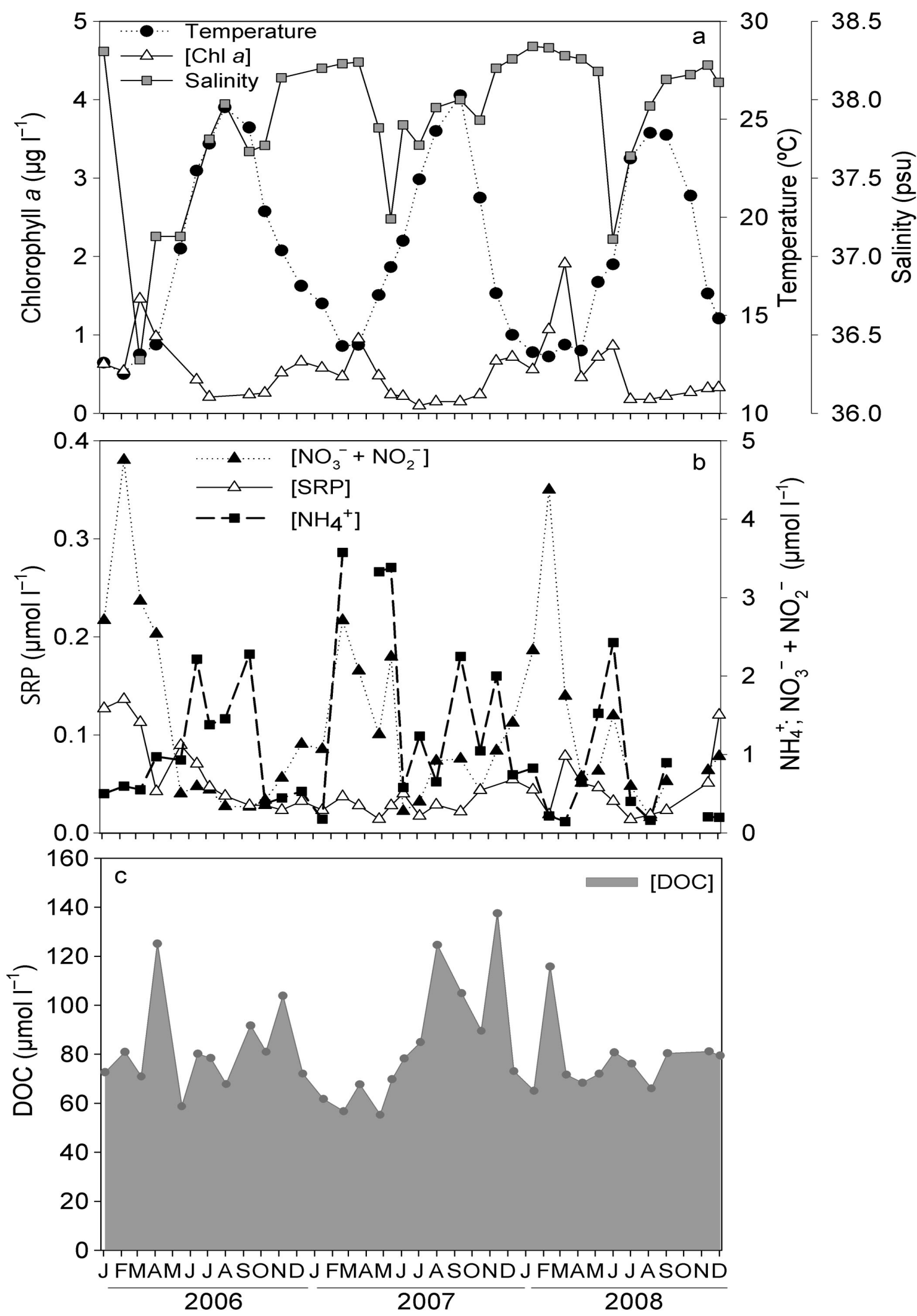

Fig. 5. Monthly measurements over the $3 \mathrm{yr}$ of (a) chlorophyll a concentration (chl a), seawater temperature and salinity, (b) soluble reactive phosphorus (SRP) and dissolved inorganic nitrogen $\left(\mathrm{NO}_{3}^{-}+\mathrm{NO}_{2}^{-} ; \mathrm{NH}_{4}{ }^{+}\right)$and (c) dissolved organic carbon concentration (DOC) in Blanes Bay Microbial Observatory surface waters 

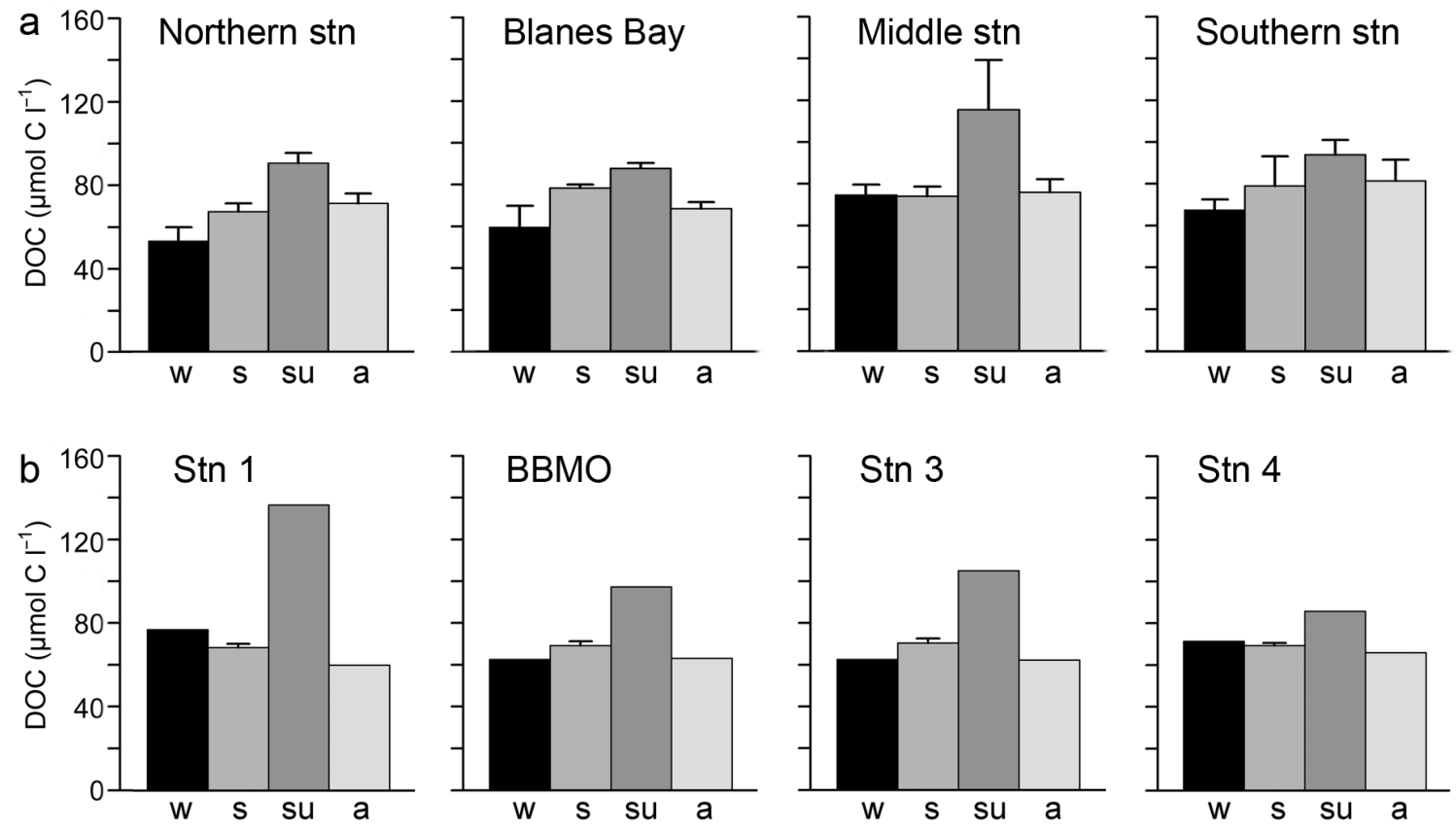

Fig. 6. Seasonal surface water value of dissolved organic carbon (DOC; mean $+\mathrm{SE}$ ) concentration in (a) the extensive sampling along the Catalan coast from north to south and (b) along the inshore-offshore transect in Blanes Bay. w: winter; s: spring; su: summer; a: autumn; BBMO: Blanes Bay Microbial Observatory

(Fig. 5c). DOC accumulation showed a seasonal pattern, with increasing concentrations from winter to summer/autumn and decreasing afterwards. This is paradoxical because the main processes producing DOC were estimated to be higher in winter and early spring, while those consuming DOC showed higher values in summer than in winter/spring (Fig. 7). This paradox seems to be widespread and has been found in other regions of the Mediterranean (Zweifel et al. 1995, Cauwet et al. 1997, Thingstad et al. 1997, Avril 2002) and in distinct places worldwide (Carlson et al. 1994, Guo et al. 1995, Hansell \& Carlson 1998b, Sintes et al. 2010). The magnitude of the increase in DOC concentration through the seasons is not always the same. For example, DOC accumulation was 2and 5-fold higher in 2007 than in 2006 and 2008, respectively.

\section{Balance of microbial food-web processes}

The analysis of the microbial food-web processes involved in the DOC balance does not solve the paradox; while our microbial food-web system showed net DOC consumption from spring to autumn, a high DOC accumulation was measured (Figs. $5 \mathrm{c} \& 8$ ). Uncertainties in the assumptions of the different terms of Eq. (1) would in part contribute to the DOC imbalance. The $11 \%$ PER found in our study agrees with the value from Hagström et al. (1988), but it was low compared to the average of $16 \%$ given by Morán et al. (2002) for the NW Mediterranean Sea and the $46 \%$ reported by Alonso-Sáez et al. (2008) at our BBMO station. PER values of up to $80 \%$ have been observed in the declining phases of phytoplankton blooms when accompanied with nutrient depletion (Lancelot 1983). Likewise, a summer PER value of $62.8 \pm 5.4 \%$ has been found in an extensive study along the Catalan coast (Guallar \& Flos unpubl. data). This corresponds to a summer dPP of $0.83 \pm 0.56 \mu \mathrm{mol}$ $\mathrm{C}^{-1} \mathrm{~d}^{-1}$, equivalent to 4 - to 7 -fold our estimated dPP and would suggest that our dPP estimates might not reflect the particular conditions of summer. Taking into account the estimated DOC shortage of about

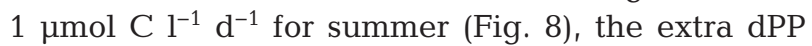
could produce a near balanced DOC budget.

The contribution of DOC from heterotrophic excretion (E) accounted for near half of the total dissolved DOC production (Fig. $7 \mathrm{~b}$ ). The finding that $56 \%$ of the daily primary production can be consumed by grazers (Gutiérrez-Rodríguez et al. 2011) seems reasonable, according to the value of $60 \%$ reported by Calbet \& Landry (2004) from a review of coastal and estuarine environments. The assumption that $20 \%$ ingestion was transformed to DOC was taken from Nagata (2000). The combination of both estimates 


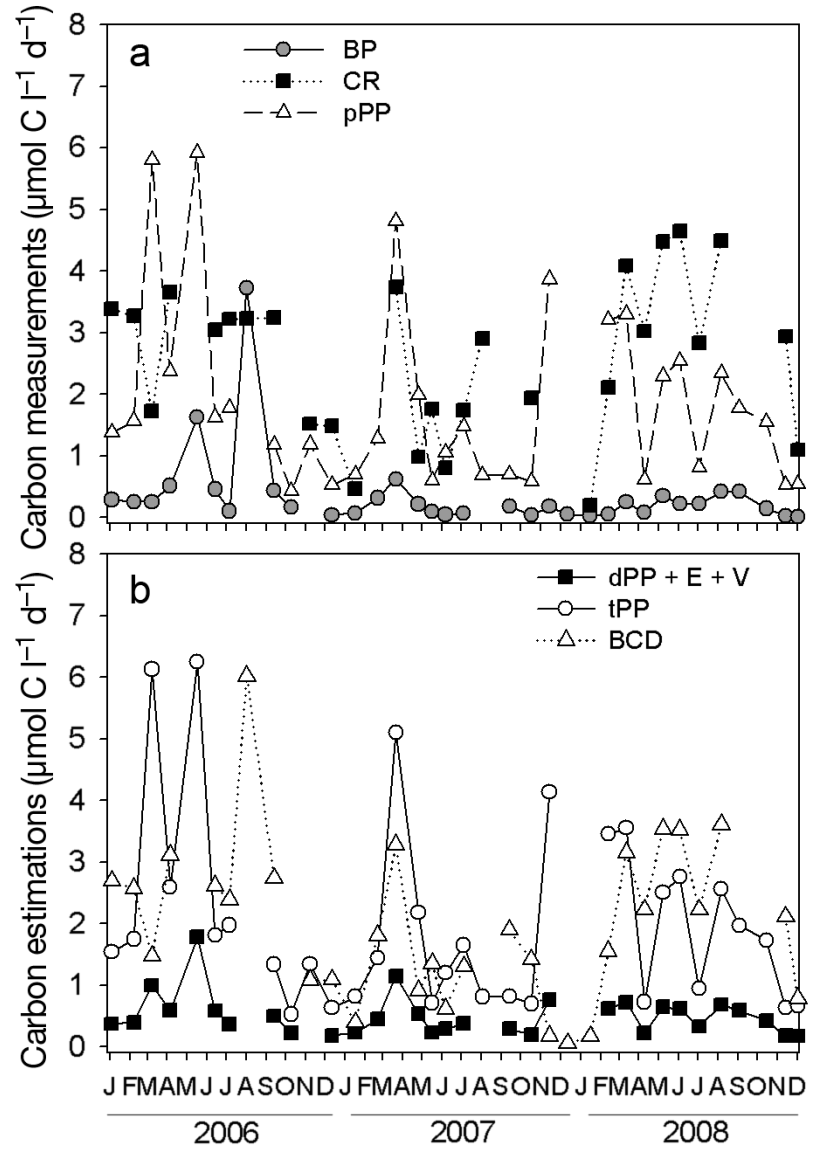

Fig. 7. (a) Monthly measurements over the $3 \mathrm{yr}$ of bacterial production (BP), community respiration (CR) and particulate primary production (pPP). (b) Time course of estimated dissolved organic carbon (DOC) production (dPP + excretion $[\mathrm{E}]+$ viral lysis $[\mathrm{V}])$, total primary production (tPP $=\mathrm{pPP}+$ $\mathrm{dPP}$ ) and bacterial carbon demand (BCD) in Blanes Bay Microbial Observatory surface waters over the $3 \mathrm{yr}$ dPP: dissolved primary production

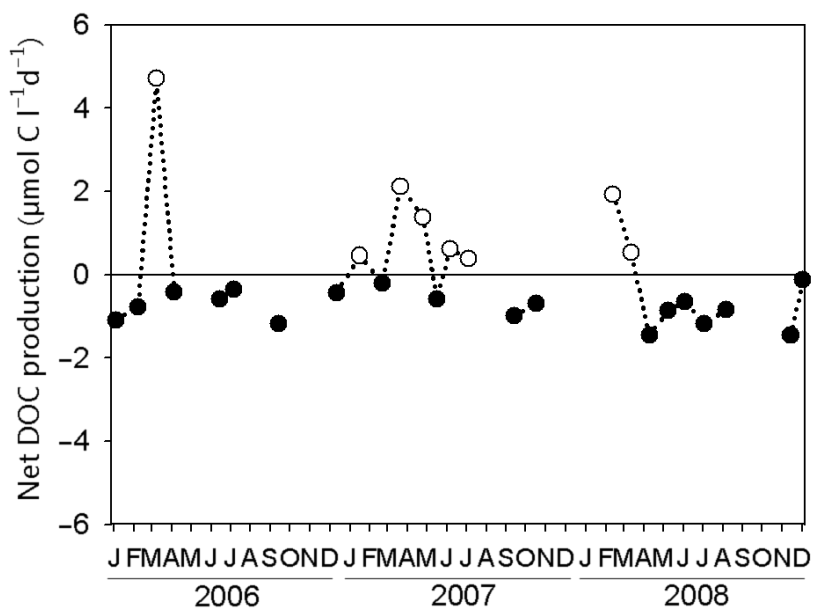

Fig. 8. Monthly net dissolved organic carbon (DOC) production using both the measured and estimated variables in Eq. (1) (see 'Net DOC production' in 'Materials and methods') over the 3 yr gives the $11 \%$ of total primary production released as DOC by heterotrophic activity, which agrees with most reports (Nagata 2000). Cell lysis induced by viruses (V) in Blanes Bay removed between 12.3 and $40.9 \%$ of daily bacterial production (Boras et al. 2009); this contribution was low, as expected from the low BP. In relation to the biological processes that remove $\mathrm{DOC}$, such as $\mathrm{BP}$ and $\mathrm{BR}$, our results are within the reported values found in the literature (Zweifel et al. 1995, Navarro et al. 2004, Alonso-Sáez et al. 2008). In a recent study in a nearby location, Trabelsi \& Rassoulzadegan (2011a) found summer

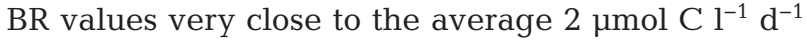
found in our study, although their winter and early spring values were lower.

The imbalance between $\mathrm{dPP}$ and BCD seems to be a common characteristic of productive coastal ecosystems, in which dPP may account for as low as $7 \%$ of BCD (Morán et al. 2002). Even the inputs of DOC from food-web processes were unable to fulfill $\mathrm{BCD}$ in most occasions. Depending on whether we consider dPP or tPP in the net DOC production equation, BCD exceeded the supply of DOC by a factor of 5.4 or 1.3. A positive net DOC balance was observed only in 2007 (Fig. 8), when the net production of

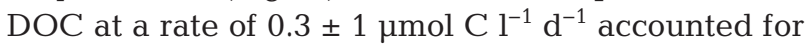

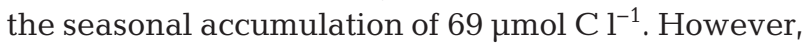
the negative DOC productions of 2006 and 2008 did not prevent DOC to accumulate to some degree. This lends support to the hypothesis of loose coupling between phytoplankton and bacteria in coastal ecosystems and to the existence of more complex net heterotrophic food-webs (Morán et al. 2002) that might use allochthonous $\mathrm{C}$ or the produced $\mathrm{C}$ with a time delay.

Unfortunately, we have no data to solve the DOC balance for all the stations studied along the coast, but it is likely that we would have found very different situations. For instance, in a summer study in the NW Mediterranean, Morán et al. (2002) showed drastic changes in the dPP:BCD ratio from the $7 \%$ found in a shelf station to the $104 \%$ found in offshore waters, reflecting a trend towards strong phytoplankton-bacterioplankton coupling in areas far from the influence of allochthonous sources. According to this, it is likely that microbial food-web processes can fulfil a greater part of the bacterial needs in the more offshore stations of our study. Therefore, the finding of extensive DOC accumulation at all the studied stations on the Catalan coast (Fig. 6), irrespective of their likely different DOC sources, points to the influence of processes other than $\mathrm{dPP}$ and BCD in determining DOC dynamics. 


\section{Why does DOC accumulate?}

Bacterial growth efficiency (BGE) was particularly low, $<10 \%$, in summer as compared to winter and spring $(20 \%)$. The low summer values agree with those found by Trabelsi \& Rassoulzadegan (2011a), which were explained by some degree of nutrient limitation of the bacterial population. Pinhassi et al. (2006) in the same Blanes Bay station (BBMO) found that bacterial $\mathrm{P}$ limitation occurred throughout the year and that it was most pronounced during summer, coinciding with very low dissolved inorganic phosphorus concentrations and chlorophyll values, like those found in our study. Indeed, P limitation of bacteria DOC consumption has also been found in nearby locations (Zweifel et al. 1995, Trabelsi \& Rassoulzadegan 2011b). Yet, the severity of P limitation may be variable among years and contribute to the interannual variability of DOC accumulation. Indeed, we found indications of accentuated P limitation in 2007, as suggested by the high DIN:SRP ratio of 82:1 (averaged for the interval May to November), compared to that of 45:1 and 58:1, for 2006 and 2008, respectively. Thus, reduced BGE and the likely increase of PER caused by strong P limitation would facilitate higher DOC accumulation in 2007. Nevertheless, the influence of structural changes in the DOM pool cannot be excluded. In a simultaneous study, Vila-Reixach \& Vidal (unpubl. data) found high DOC:DOP ratios and an increase of refractivity in summer DOM. Laboratory studies have proved that amino acids and protein can be an important component of this refractory DOM because they are protected against microbial degradation (Keil \& Kirchman 1994, Ogawa et al. 2001). According to Yamashita \& Tanoue (2003), a by-product of bacterial metabolism is tryptophan, an amino acid which forms part of the refractory DOM. The high aromatic amino acid concentration found during the summer/autumn period from 2006 to 2009 in the same region $(10 \mu \mathrm{mol}$ tryptophan $\mathrm{l}^{-1}$; Vila-Reixach \& Vidal unpubl. data) would support that this process is occurring in the area. Bacterial cell wall components resulting from protozoan grazing and viral lysis can be another source of low-reactivity DOC as reported by McCarthy et al. (1998). In Blanes Bay, this source can have a seasonal component, due to the higher rates of heterotrophic flagellate grazing activity and viral lysis observed in summer (Unrein et al. 2007, Boras et al. 2009). Photochemical reactions can also be a source of refractory DOC during the summer. In a near location, Tedetti et al. (2009) found a negative effect of ultraviolet radiation on bacterial production in their
July experiments, which they explained by the transformation of labile DOM molecules into refractory compounds. Indeed, Sommaruga et al. (2005) found high ultraviolet penetration in Blanes during the summer, which would suggest that the recalcitrant nature of the seasonally accumulated DOC may constrain bacterial consumption as much as nutrient limitation (Søndergaard et al. 2000, Carlson et al. 2002, 2004).

\section{Influence of physical processes}

The different DOC accumulation episodes could be favoured by physical processes that modify the water renewal rate at the local scale, such as wind direction and river flow. Wind seasonality involves strong NW winds from November to May and weak SE winds in summer, from late May to October (Fig. 2b). The predominance of strong northerly winds from November to April in the area (77\% of the days), also observed in other studies (Bolaños et al. 2009, Guadayol et al. 2009), caused a surface horizontal displacement of water and, as a consequence, coastal upwelling (Herrera \& Margalef 1957). In our study, this can be seen in the increased salinity, inorganic nutrient concentrations and decreased temperature found in all winters (Fig. 5a). Indeed, the significant correlation found between salinity and wind direction $(\mathrm{r}=$ $0.7, \mathrm{p}<0.0001, \mathrm{n}=35$ ) points to the main influence of dominant winds.

The autumn to winter dominance of strong NW winds causes high water renewal (average $0.11 \pm$ $0.048 \mathrm{~d}^{-1}$ from November to April; Fig. 3) which promote high offshore water transport, hence removing surface DOC from shelf waters towards the open ocean. By contrast, the low water renewal rate (average $0.037 \pm 0.021 \mathrm{~d}^{-1}$ from May to October), the increased stratification and the possible confinement of shelf water associated to SE winds throughout the summer, can help explain the seasonal DOC accumulation. High $\mathrm{NH}_{4}{ }^{+}$concentrations during the summer/ autumn (Fig. 5b) also support low water renewal. Furthermore, the inverse correlation found between the DOC accumulated each year and summer rainfall suggests that water renewal can have an influence on the interannual variability of DOC accumulation.

To summarize, we found summer/autumn DOC accumulation in an extensive sampling along the Catalan coast. The mass balance of microbial food-web processes involved in DOC dynamics did not reveal the underlying causes, since seasonal DOC accumulation occurred with negative net DOC production. 
The complex network of DOC sources to coastal ecosystems, with the possible influence of allochthonous inputs, can partly explain DOC accumulation. The extensive DOC accumulation at all the studied stations, irrespective of their likely different DOC sources, however, requires additional explanation. Summer P limitation has been proposed as a key factor, through its effect on phytoplankton DOC excretion, bacterial DOC utilization and the structural composition and lability of the DOM pool. Besides, the high grazing activity, viral lysis and ultraviolet radiation in summer could also contribute to increase the refractory DOM pool. Nevertheless, DOC accumulation is constrained by the residence time of water on the shelf. We hypothesize that both the decreased DOC turnover due to biological and photochemical processes and the low summer water renewal appear as the key factors determining DOC seasonality as well as DOC interannual variability in the region.

Acknowledgements. This work was supported by the Spanish project FLUBIOLIT (CTM 2004-04404-C02-02/MAR). The work of G.V.R. and M.V. was supported by the project FAMOSO (CTM2008-06261-C03-01). The work of C.C. and J.M.G. was supported by the projects MODIVUS (CTM 2005-04795/MAR) and STORM (CTM2009-09352/MAR), and sampling was also contributed by the projects PROBA (2007AR0018, CSIC) and GEMMA (CTM2007-63753-C0201/MAR, MEC) to R. Massana and C. Pedrós-Alió. Financial support was provided by a $\mathrm{PhD}$ fellowship from the Spanish government to G.V.R. We thank Carles Guallar, Jordi Flos and Jordi Griso for their help with field sampling in the inshore-offshore and Catalan coast transects, V. Balagué and I. Forn for help with the Blanes Bay sampling, and I. Lekunberri, C. Ruiz-González, H. Sarmento and A. Gomes for the bacterial production determinations. E. VázquezDomínguez supervised the respiration measurements, and M. Galí helped with the salinity data. We also thank G. Basterretxea for his valuable contribution. The Catalan Meteorological Service provided meteorological data from Malgrat de Mar, and the Catalan Water Agency (ACA) provided data on La Tordera River discharge and also financed the Catalan coast transect sampling.

\section{LITERATURE CITED}

> Alonso-Sáez L, Vázquez-Domínguez E, Cardelús C, Pinhassi J and others (2008) Factors controlling the yearround variability in carbon flux through bacteria in a coastal marine system. Ecosystems 11:397-409

> Avril B (2002) DOC dynamics in the northwestern Mediterranean Sea (DYFAMED site). Deep-Sea Res II 49: 2163-2182

> Basterretxea G, Garcés E, Jordi A, Anglès S, Masó M (2007) Modulation of nearshore harmful algal blooms by in situ growth rate and water renewal. Mar Ecol Prog Ser 352: $53-65$

Biddanda B, Benner R (1997) Carbon, nitrogen, and carbohydrate fluxes during the production of particulate and dissolved organic matter by marine phytoplankton. Limnol Oceanogr 42:506-518

Biersmith A, Benner R (1998) Carbohydrates in phytoplankton and freshly produced dissolved organic matter. Mar Chem 63:131-144

Bolaños R, Jorda G, Cateura J, Lopez J, Puigdefabregas J, Gomez J, Espino M (2009) The XIOM: 20 years of a regional coastal observatory in the Spanish Catalan Coast. J Mar Syst 77:237-260

> Boras JA, Sala MM, Vázquez-Domínguez E, Weinbauer MG, Vaqué D (2009) Annual changes of bacterial mortality due to viruses and protists in an oligotrophic coastal environment (NW Mediterranean). Environ Microbiol 11: 1181-1193

Børsheim KY, Myklestad SM (1997) Dynamics of DOC in the Norwegian Sea inferred from monthly profiles collected during 3 years at $66^{\circ} \mathrm{N}, 2^{\circ} \mathrm{E}$. Deep-Sea Res I 44:593-601

Calbet A, Landry MR (2004) Phytoplankton growth, microzooplankton grazing and carbon cycling in marine systems. Limnol Oceanogr 49:51-57

Carlson CA (2002) Production and removal processes. In: Hansell DA, Carlson CA (eds) Biogeochemistry of marine dissolved organic matter. Academic Press, San Diego, CA, p 92-151

> Carlson CA, Ducklow HW, Michaels AF (1994) Annual flux of dissolved organic-carbon from the euphotic zone in the northwestern Sargasso Sea. Nature 371:405-408

> Carlson CA, Giovannoni SJ, Hansell DA, Goldberg SJ and others (2002) Effect of nutrient amendments on bacterioplankton production, community structure, and DOC utilization in the northwestern Sargasso Sea. Aquat Microb Ecol 30:19-36

> Carlson CA, Giovannoni SJ, Hansell DA, Goldberg SJ, Parsons R, Vergin K (2004) Interactions among dissolved organic carbon, microbial processes, and community structure in the mesopelagic zone of the northwestern Sargasso Sea. Limnol Oceanogr 49:1073-1083

Cauwet G (2002) DOM in the coastal zone. In: Hansell DA, Carlson CA (eds) Biogeochemistry of marine dissolved organic matter. Academic Press, San Diego, CA, p 579-609

Cauwet G, Miller A, Brasse S, Fengler G, Mantoura RFC, Spitzy A (1997) Dissolved and particulate organic carbon in the western Mediterranean Sea. Deep-Sea Res II 44: 769-779

> Copin-Montégut G, Avril B (1993) Vertical distribution and temporal variation of dissolved organic carbon in the north-western Mediterranean Sea. Deep-Sea Res I 40: 1963-1972

> Duarte CM, Agustí S, Kennedy H, Vaqué D (1999) The Mediterranean climate as a template for Mediterranean marine ecosystems: the example of the northeast Spanish littoral. Prog Oceanogr 44:245-270

Fajon C, Cauwet G, Lebaron P, Terzic S and others (1999) The accumulation and release of polysaccharides by planktonic cells and the subsequent bacterial response during a controlled experiment. FEMS Microbiol Ecol 29: 351-363

Fasham MJF, Balino B, Bowles M (2001) Ocean biogeochemistry and climate change: JGOFS achievements 1988-2000. Ambio 10:4-31

Font J, Garcia-Ladona E, Gorriz EG (1995) The seasonality of mesoscale motion in the Northern Current of the western Mediterranean: several years of evidence. Oceanol Acta 18:207-219

Grasshoff K, Kremling K, Ehrhardt M (1999) Methods of 
seawater analysis, 3rd edn. Verlag Chemie, Weinheim

Guadayol Ò, Peters F, Marrasé C, Gasol JM and others (2009) Episodic meteorological and nutrient-load events as drivers of coastal planktonic ecosystem dynamics: a time-series analysis. Mar Ecol Prog Ser 381:139-155

Guo L, Santschi PH, Warnken KW (1995) Dynamics of dissolved organic carbon (DOC) in oceanic environments. Limnol Oceanogr 40:1392-1403

Gutiérrez-Rodríguez A, Latasa M, Scharek R, Massana R, Vila G, Gasol JM (2011) Carbon fluxes through the main phytoplankton groups in an oligotrophic coastal site (Blanes Bay, NW-Mediterranean). Estuar Coast Shelf Sci 95:77-87

Hagström A, Azam F, Andersson A, Wikner J, Rassoulzadegan F (1988) Microbial loop in an oligotrophic pelagic marine ecosystem: possible roles of cyanobacteria and nanoflagellates in the organic fluxes. Mar Ecol Prog Ser 49:171-178

Hansell DA, Carlson CA (1998a) Deep-ocean gradients in the concentration of dissolved organic carbon. Nature 395:263-266

> Hansell DA, Carlson CA (1998b) Net community production of dissolved organic carbon. Global Biogeochem Cycles 12:443-453

Herrera J, Margalef R (1957) Hidrografia y fitoplancton de las costas de Castellón, de julio de 1956 a junio de 1957. Invest Pesq (Spain) 10:17-44

$>$ Keil RG, Kirchman DL (1994) Abiotic transformation of labile protein to refractory protein in sea water. Mar Chem 45:187-196

Kirchman D, K'nees E, Hodson R (1985) Leucine incorporation and its potential as a measure of protein synthesis by bacteria in natural aquatic systems. Appl Environ Microbiol 49:599-607

Lancelot C (1983) Factors affecting phytoplankton extracellular release in the Southern Bight of the North Sea. Mar Ecol Prog Ser 12:115-121

> Legendre L, Le Fèvre J (1995) Microbial food webs and the export of biogenic carbon in oceans. Aquat Microb Ecol 9:69-77

McCarthy MD, Hedges JI, Benner R (1998) Major bacterial contribution to marine dissolved organic nitrogen. Science 281:231-234

Morán XAG, Estrada M, Gasol JM, Pedrós-Alió C (2002) Dissolved primary production and the strength of phytoplankton-bacterioplankton coupling in contrasting marine regions. Microb Ecol 44:217-223

Nagata T (2000) Production mechanisms of dissolved organic matter. In: Kirchman DL (ed) Microbial ecology of the oceans. Wiley-Liss, New York, NY, p 121-153

- Navarro N, Agustí S, Duarte CM (2004) Plankton metabolism and dissolved organic carbon use in the Bay of Palma, NW Mediterranean Sea. Aquat Microb Ecol 37:47-54

Ogawa H, Amagai Y, Isao K, Kaiser K, Benner R (2001) Production of refractory dissolved organic matter by bacteria. Science 292:917-920

Oudot C, Gerard R, Morin P, Gningue I (1988) Precise shipboard determination of dissolved oxygen (Winkler procedure) for productivity studies with a commercial system. Limnol Oceanogr 33:146-150

> Pinhassi J, Gómez-Consarnau L, Alonso-Sáez L, Sala MM, Vidal M, Pedrós-Alió C, Gasol JM (2006) Seasonal

Editorial responsibility: Ronald Kiene,

Mobile, Alabama, USA changes in bacterioplankton nutrient limitation and their effects on bacterial community composition. Aquat Microb Ecol 44:241-252

Price JF, Weller RA, Pinkel R (1986) Diurnal cycling: observations and models of the upper ocean response to heating, cooling and wind mixing. J Geophys Res 91: 8411-8427

Sabatés A, Salat J, Olivar PM (2001) Advection of continental water as an export mechanism for anchovy, Engraulis encrasicolus, larvae. Sci Mar 65:77-87

Schlesinger WH (1997) Biogeochemistry: an analysis of global change. Academic Press, San Diego, CA

> Sintes E, Stoderegger K, Parada V, Herndl GJ (2010) Seasonal dynamics of dissolved organic matter and microbial activity in the coastal North Sea. Aquat Microb Ecol 60:85-95

Smith DC, Azam F (1992) A simple, economical method for measuring bacterial protein synthesis rates in seawater using 3H-leucine. Mar Microb Food Webs 6:107-114

Sommaruga R, Hofer JS, Alonso-Sáez L, Gasol JM (2005) Differential sunlight sensitivity of picophytoplankton from surface Mediterranean coastal waters. Appl Environ Microbiol 71:2154-2157

Søndergaard M, Williams PJL, Cauwet G, Riemann B and others (2000) Net accumulation and flux of dissolved organic carbon and dissolved organic nitrogen in marine plankton communities. Limnol Oceanogr 45:1097-1111

Strom SL, Benner R, Ziegler S, Dagg MJ (1997) Planktonic grazers are a potentially important source of marine dissolved organic carbon. Limnol Oceanogr 42:1364-1374

Suttle CA (2007) Marine viruses-major players in the global ecosystem. Nat Rev Microbiol 5:801-812

> Tedetti M, Joux F, Charriere B, Mopper K, Sempéré R (2009) Contrasting effects of solar radiation and nitrates on the bioavailability of dissolved organic matter to marine bacteria. J Photochem Photobiol Chem 201:243-247

> Thingstad FT, Hagström A, Rassoulzadegan F (1997) Accumulation of degradable DOC in surface waters: Is it caused by a malfunctioning microbial loop? Limnol Oceanogr 42:398-404

Trabelsi A, Rassoulzadegan F (2011a) Effect of bacterial community dynamics on DOC seasonal changes in the north-western Mediterranean Sea. J Plankton Res 33: 1249-1262

> Trabelsi A, Rassoulzadegan F (2011b) Inorganic nutrient control of dissolved organic carbon (DOC) dynamics in NW Mediterranean waters: an experimental approach. Mar Biol Res 7:667-676

Unrein F, Massana R, Alonso-Sáez L, Gasol JM (2007) Significant year-round effect of small mixotrophic flagellates on bacterioplankton in an oligotrophic coastal system. Limnol Oceanogr 52:456-469

Williams PJleB, Giorgio PA (2004) Respiration in aquatic ecosystems: history and background. In: del Giorgio PA, Williams PJleB (eds) Respiration in aquatic ecosystems. Oxford University Press, Oxford, p 1-17

Yamashita Y, Tanoue E (2003) Chemical characterization of protein-like fluorophores in DOM in relation to aromatic amino acids. Mar Chem 82:255-271

> Zweifel UL, Wikner J, Hagström A, Lundberg E, Norrman B (1995) Dynamics of dissolved organic carbon in a coastal ecosystem. Limnol Oceanogr 40:299-305

Submitted: January 17, 2011; Accepted: February 15, 2012 Proofs received from author(s): May 17, 2012 